\title{
Abelmoschus esculentus subfractions attenuate $A \beta$ and tau by regulating DPP-4 and insulin resistance signals
}

\author{
Chien-Ning Huang ${ }^{1,2}$, Chau-Jong Wang ${ }^{3}$, Chih-Li Lin ${ }^{2}$, Hsin-Hua Li ${ }^{2}$ An-Ting Yen ${ }^{3}$ and Chiung-Huei Peng ${ }^{4^{*}}$ (D)
}

\begin{abstract}
Background: Insulin resistance could be associated with the development of Alzheimer disease (AD). The neuropathological hallmarks of $A D$ are beta amyloid $(A \beta)$ produced from sequential cleavage initiated by $\beta$-secretase and degraded by insulin degradation enzyme (IDE), as well as hyperphosphorylation of tau (p-tau). Insulin action involves the cascades of insulin receptor substrates (IRS) and phosphatidylinositol 3-kinase (PI3K), while phosphorylation of IRS-1 at ser307 (p-ser307IRS-1) hinders the response. Our previous report suggested dipeptidyl peptidase-4 (DPP-4) is crucial to insulin resistance, and the subfractions of Abelmoschus esculentus (AE), F1 and F2, attenuate the signaling. Here we aim to investigate whether AE works to reduce A $\beta$ generation via regulating DPP4 and insulin resistance.

Methods: The subfractions F1 and F2 were prepared according to a succession of procedures. F1 was composed by quercetin glycosides and triterpene ester, and F2 contained a large amount of polysaccharides. The in vitro insulin resistance model was established by SK-N-MC cell line treated with palmitate. MTT was used to define the dose range, and thereby Western blot, ELISA, and the activity assay were used to detect the putative markers. One-way ANOVA was performed for the statistical analysis.
\end{abstract}

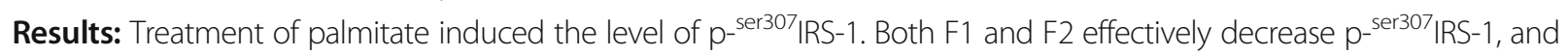
recover the expression of p-PI3K. However, the expression of total IRS plunged with $25 \mu \mathrm{g} / \mathrm{mL}$ of F1, while descended steadily with $5 \mu \mathrm{g} / \mathrm{mL}$ of $\mathrm{F} 2$. As palmitate increased the levels of $A \beta 40$ and $A \beta 42$, both $A E$ subfractions were effective to reduce $A \beta$ generation of and $\beta$-secretase activity, but IDE was not altered in any treatment conditions. The expression of DPP4 was also accompanied with insulin resistance signals. Inhibition of DPP4 attenuated the activity of $\beta$-secretase and production of A $\beta$. Moreover, the present data revealed that both AE subfractions significantly decrease the level of $p$-Tau.

Conclusions: In conclusion, we demonstrated that AE would be a potential adjuvant to prevent insulin resistance and the associated pathogenesis of AD, and F2 seems more feasible to be developed.

Keywords: Abelmoschus esculentus, Beta amyloid, Insulin resistance, Dipeptidyl peptidase-4

\footnotetext{
* Correspondence: a222907@sunrise.hk.edu.tw

${ }^{4}$ Division of Basic Medical Science, Hungkuang University, Taichung City,

Taiwan

Full list of author information is available at the end of the article
}

(c) The Author(s). 2020 Open Access This article is licensed under a Creative Commons Attribution 4.0 International License, which permits use, sharing, adaptation, distribution and reproduction in any medium or format, as long as you give appropriate credit to the original author(s) and the source, provide a link to the Creative Commons licence, and indicate if changes were made. The images or other third party material in this article are included in the article's Creative Commons licence, unless indicated otherwise in a credit line to the material. If material is not included in the article's Creative Commons licence and your intended use is not permitted by statutory regulation or exceeds the permitted use, you will need to obtain permission directly from the copyright holder. To view a copy of this licence, visit http://creativecommons.org/licenses/by/4.0/ The Creative Commons Public Domain Dedication waiver (http://creativecommons.org/publicdomain/zero/1.0/) applies to the data made available in this article, unless otherwise stated in a credit line to the data. 


\section{Background}

Insulin resistance is related with obesity and metabolic syndrome. The worldwide increasing prevalence of diabetes, especially the type 2 characterized by insulin resistance and hyperinsulinemia, burdens the public health. Likewise, the incidence of Alzheimer disease (AD) is raised at alarming rate in aging society of many developed countries [1]. It is noteworthy that diabetic individuals showed higher risk to develop $\mathrm{AD}[2,3]$, and the clinical observation revealed the association is independent of vascular factor [4].

The neuropathological hallmarks of AD are intercellular beta amyloid $(A \beta)$ accumulation and intracellular neurofibrillary tangling. $A \beta$ is a 38 - to 43-amino acid peptide which is produced by sequential cleavage of amyloid precursor protein (APP) with $\beta$ and $\gamma$-secretase, respectively. Insulin degradation enzyme (IDE) is one of the major enzymes degrading $A \beta$. An imbalance between production and clearance of $\mathrm{A} \beta$ forms senile plaque, an early and often initiating factor of AD. The neurofibrillary tangling is composed of hyperphosphorylated tau (p-tau), a group of proteins assembly to stabilize microtubules. Both $\mathrm{A} \beta$ and $\mathrm{p}$-tau spread in a progressive manner with characteristic "regional specificity", eventually leading to neuron loss and memory impairment [5].

In addition to exist in peripheral organs, insulin receptors also appear in central nervous system, especially hippocampus and cerebral cortex which play the pivotal role in learning and memory [6]. After binding to its receptor, the insulin action involves a series of cascades by eliciting tyrosine phosphorylation of insulin receptor substrates (IRS), leading to the activation of phosphatidylinositol 3-kinase (PI3K). An increase of phosphorylation of IRS-1 at the residue ser307 ( $\mathrm{p}^{-}{ }^{\text {ser307 IRS-1) }}$ hinders the insulin response and glucose utilization, thus viewed as the insulin resistance marker [7]. Moreover, as dipeptidyl peptidase-4 (DPP-4) inhibitors have emerged as a useful tool in treating type 2 diabetes, our previous reports showed that DPP-4 activity is crucial to the downstream insulin resistance signals [8].

In literature, it has been shown the close relationship between insulin and $A \beta$ metabolism. Insulin resistance accelerated the assembly of $A \beta$ by inducing GM1 ganglioside clustering in the presynaptic membranes [9]. Insulin raised the extracellular level of $A \beta$ by increasing its release [10], or modulating the secretase activity [11]. IDE could be competitively inhibited by insulin, resulting in decreased degradation of $A \beta[12,13]$. It was suggested IDE acts as the junction point of type 2 diabetes and AD [14]. Induced by excessive sucrose intake, insulin resistance increased cerebral $A \beta$ peptide levels and exacerbated learning impairment in AD transgenic mice [15]. In AD-like mouse model, combination of insulin with GLP1 agonist reduced the expression of effector genes involved in insulin receptor signaling. Cortical A $\beta$ levels were also decreased by $15-30 \%$, accompanied with better learning [16]. These revealed that there is the close relation between $\mathrm{AD}$ and insulin resistance.

Abelmoschus esculentus (AE) fruit is consumed as vegetable and famous in folklore medicine because of its antidiabetic effect $[17,18]$, whereas the substantial mucilage makes it difficult to test the active components. In our previous studies, we isolated several subfractions from $\mathrm{AE}$ using a series of successive extraction steps, and found that F1 (the subfraction rich in quercetin glucosides and pentacyclic triterpene ester) and F2 (the subfraction containing large amounts of carbohydrates and polysaccharides) were particularly effective in suppressing DPP-4 signaling [19-21]. Recently, we reported that AE is potential to prevent $A \beta$-induced neuron damage by regulating DPP-4 and the insulin resistance cascades [22].

In the present study, we aimed to investigate whether $\mathrm{AE}$ could be effective to attenuate $A \beta$ generation and metabolism, via regulating DPP4 and insulin resistance cascades.

\section{Methods \\ Preparation of AE subfractions and chemical analysis}

The fruit of AE was purchased from Chiayi, Taiwan. The subfractions F1 and F2 were prepared according to a succession of procedures [19]. F1, the alcohol-extracted fraction of AE, has been analyzed with LC-MS/MS. At least 10 compounds were found in F1, including quercetin glucosides $(4.901 \mathrm{mg} / \mathrm{g} \mathrm{DW})$ and pentacyclic triterpene ester $(4.301 \mathrm{mg} / \mathrm{g} \mathrm{DW}$ ) (The content was estimated in comparison with the standard). F2 contains a large amount of polysaccharides. With gel filtration chromatography (GPC) analysis, the mean molecular weight of F2 was estimated to be $671 \mathrm{kDa}$. The monosaccharide analysis and uronic determination revealed that F2 is rich in uronic acid (23.14\%), galactose (18.92\%), glucose (18.26\%) and myoinositol (14.21\%); rhamnose, fucose and glucosamine were also found to be quite abundant [19].

\section{Cell culture}

The cell line SK-N-MC was obtained from American Type Culture Collection (ATCC). Cells were cultured in Minimum Essential Medium (MEM), with $2 \mathrm{mM} \mathrm{L-glu-}$ tamine and penicillin-streptomycin, and 10\% fetal bovine serum (FBS), and grown in a humidified incubator at $37^{\circ} \mathrm{C}, 5 \% \mathrm{CO} 2$. The medium was changed every 2 or 3 days. When the cells reached approximately $80 \%$ confluency, the subcultures were undergone. The phase contrast microscope with photo-system was used for image observation.

\section{MTT}

Cells were seeded on the 24 well-plate at a density of $2 \times 10^{5}$ cells $/ \mathrm{mL}$. After attachment, cells were incubated 
with palmitate with or without $\mathrm{AE}$ subfractions at various concentrations for $24 \mathrm{~h}$. The medium was changed and cells were incubated with $0.5 \mathrm{mg} / \mathrm{mL} 3-(4,5-$ dimethyl-2-thiazol)-2, 5-diphenyltetrazolium bromide (MTT, CAS 298-93-1) for $2 \mathrm{~h}$. The amount of viable cells was directly proportional to the production of formazan. Following the dissolution with isopropanol (1 $\mathrm{mL} /$ well) and centrifugation (at $12000 \mathrm{rpm}$ ), each sample was added into a 96 well-plate $(200 \mu \mathrm{L}$ per well), and the absorbance was measured on spectrophotometer at 563 nm (Hitachi, U-3210).

\section{Western blot}

Cells were harvested with lysis buffer containing $50 \mathrm{mM}$ Tris $\mathrm{HCl}$ (pH 6.8), 10\% glycerol, 2\% SDS, and 5\% mercaptoethanol, and then lysed by sonication. Cell lysate was centrifuged at $9300 \mathrm{~g}$ for $20 \mathrm{~min}$ at $4{ }^{\circ} \mathrm{C}$, and then the supernatant was collected as protein samples. After quantification with Bradford assay, equal amount of protein sample $(50 \mu \mathrm{g})$ was subjected to $10 \%$ SDSpolyacrylamide gel electrophoresis, and transferred to nitrocellulose membranes (Millipore, Bedford, MA, USA). The membranes were blocked with $5 \%$ nonfat milk powder with $0.1 \%$ Tween-20 in TBS, and incubated with the primary antibody overnight at $4{ }^{\circ} \mathrm{C}$ against the following targets: pPI3K (1:200), PI3K (1:200), p- ${ }^{\text {ser307- }}$ IRS-1 (1:1000), IRS-1(1:200), IDE (1:5000), and p-Tau (1: 1000). The antibody of PI3K and IRS-1 were from Santa Cruz (Sc-374,534 and Sc-7200, respectively), and p-PI3K was from Bioss (Bs-3332R). Antibodies of p- ${ }^{\text {ser307 IRS-1 }}$ was from Cell Signaling Technology (2381S), p-Tau was from Merck Millipore (MAB5450), and IDE was from Thermo (PA5-29350). After this, the membranes were washed three times with $0.1 \%$ Tween-20 in TBS, and incubated with the secondary antibody (1:5000) conjugated to horseradish peroxidase (GE Healthcare, Little Chalfont, Buckinghamshire, UK). The band detection was thereafter fulfilled by enhanced chemiluminescence with ECL western blotting detection reagents and FUJFILM Las-3000 (Tokyo, Japan). Protein quantity was determined by densitometry using FUJFILM-Multi Gauge V2.2 software.

\section{DPP-4 activity}

Cells were seeded on $6 \mathrm{~cm}$-dish at a density of $1 \times 10^{6}$. After treated with various conditions, cells of each well were lysed with $100 \mu \mathrm{L}$ of NP-40 lysis buffer (containing $10 \mathrm{mM}$ HEPES (pH 7.5), $142.5 \mathrm{mM} \mathrm{KCl}, 5 \mathrm{mM} \mathrm{MgCl}$, $1 \mathrm{mM}$ EGTA, and $0.2 \% \mathrm{NP}-40$ ), and then centrifuged at $9300 \mathrm{~g}$ for $20 \mathrm{~min}$ at $4{ }^{\circ} \mathrm{C}$. The supernatants were collected, and the protein concentrations were determined with Bradford assay. DPP4 activity was measured using DPP4/ CD26 assay kit for biological samples (Enzo Life Sciences). Briefly, H-Gly-Pro-pNA, a chromogenic substrate of DPP-4, was hydrolysed into dipeptide GlyPro and 4-nitroaniline, whose appearance rate was measured spectrophotometrically at $405 \mathrm{~nm}$. The activity was normalized with protein concentration, and then leveled in proportion to the control. For analyzing the putative role of DPP-4, linagliptin was used to inhibit the activity of DPP-4.

\section{$A \beta$ generation}

Cells were treated with different conditions, with or without $50 \mu \mathrm{M}$ of palmitate added with $\mathrm{F} 1$ (1, 5, and $25 \mu \mathrm{g} / \mathrm{mL}$, respectively) or F2 $(1,2.5$, and $5 \mu \mathrm{g} / \mathrm{mL}$, respectively), and the medium was collected. Each sample was analyzed with $A \beta 42$ and $A \beta 40$ ELISA Kit, which are the products of Invitrogen, encoded as \#KHB3441 and \#KHB3481, respectively,

\section{$\beta$-Secretase activity}

Beta-secretase Activity kit (fluorometric), was the product of Abcam (\#ab65357). The protocol uses a secretasespecific peptide conjugated with two reporter molecules (EDANS and DABCYL). Cleavage of the peptide by beta secretase physically separates the two molecules, allowing for the release of fluorescent signals.

\section{Statistical analysis}

The statistical software SPSS v.12.0 was used to analyze the data. One-way ANOVA was performed $(p<0.05)$, while Bonferroni's multiple comparison was used for post-test.

\section{Results}

Concentrations applied were tested for the safety range

In the present study, palmitate was used to induce insulin resistance but not cell death. At beginning of the experiment, we used MTT to test the operating dose of palmitate. Figure 1 showed that palmitate reduced the cell viability dose-dependently above $50 \mu \mathrm{M}$. As for $\mathrm{AE}$, F1 and F2 had been tested to the cell line SK-N-MC in our previous work, and the maximum dose were defined as $25 \mu \mathrm{g} / \mathrm{mL}$ and $5 \mu \mathrm{g} / \mathrm{mL}$, respectively [22]. Treatment of $50 \mu \mathrm{M}$ of palmitate with different doses of F1 and F2 revealed that it would not harm the cell. Hence these dose ranges were chosen and applied in the following manipulation.

\section{AE attenuate insulin resistance signals induced by palmitate}

Figure 2a showed that palmitate increased the phosphorylation of $\mathrm{p}^{-}{ }^{\mathrm{ser} 307}$ IRS-1 about 1.5 folds. Treatment with $\mathrm{F} 1$, at $25 \mu \mathrm{g} / \mathrm{mL}$, significantly decreased $\mathrm{p}-{ }^{\mathrm{ser} 307}$ IRS- 1 to the level even below the control. The expression of total IRS was also increased by palmitate, and extremely lowered by $25 \mu \mathrm{g} / \mathrm{mL}$ of $\mathrm{F} 1$. In contrast, the expression of $\mathrm{p}$ - 

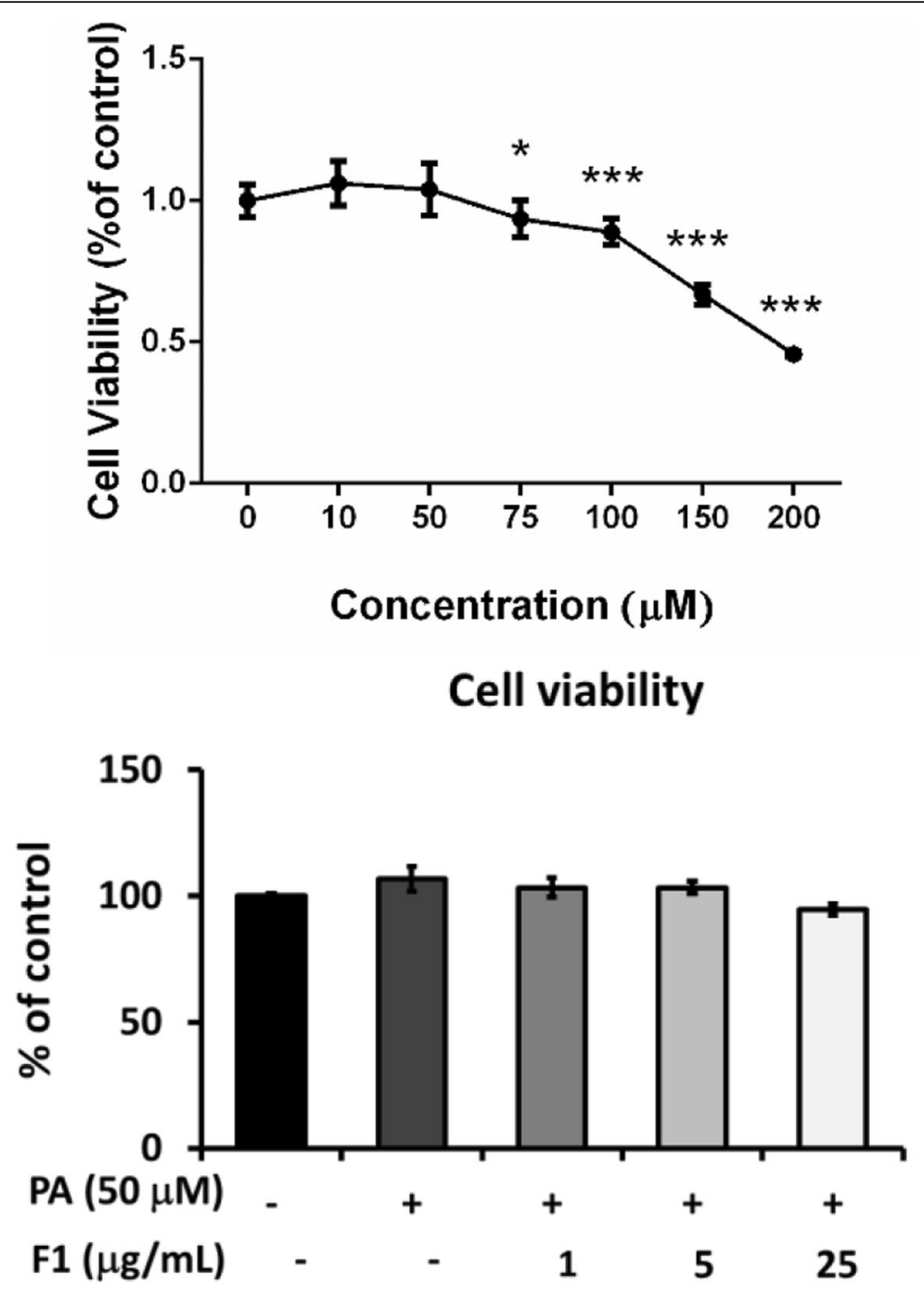

Cell viability

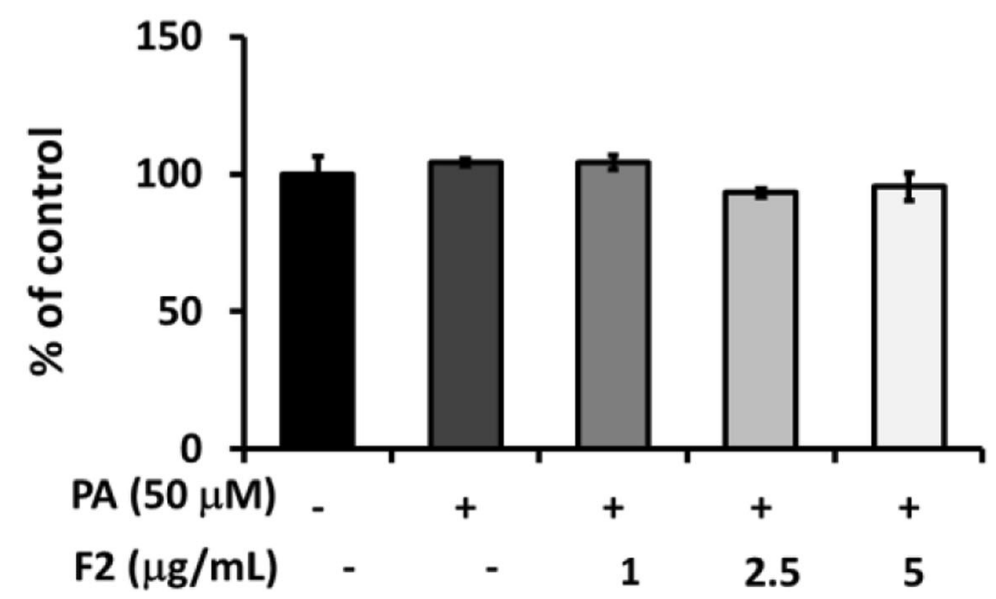

Fig. 1 (See legend on next page.) 
(See figure on previous page.)

Fig. 1 Cytotoxicity of palmitate and AE subfractions. SK-N-MC cells were incubated for $24 \mathrm{~h}$ with or without different concentrations of palmitate. The cell viability was analyzed with MTT and calculated as a percentage compared with that of the control group. $50 \mu \mathrm{M}$ of palmitate was determined to be used in the following experiment, treated with different concentrations of F1 and F2. All the data were presented as means \pm SD $(n=3)$, and statistically analyzed with ANOVA. ${ }^{*} p<0.05,{ }^{* *} p<0.01,{ }^{* * *} p<0.001$, compared with the control

PI3K was half-reduced by palmitate and returned by F1, while the expression of PI3K was altered neither by palmitate nor F1.

F2 had the similar ability to counterwork palmitate (Fig. 2b). At $5 \mu \mathrm{g} / \mathrm{mL}$, F2 effectively attenuated the level of p- ${ }^{\text {ser307}}$ IRS-1 and IRS. It is noteworthy that even at a low dose of $1 \mu \mathrm{g} / \mathrm{mL}, \mathrm{F} 2$ significantly recovered the phosphorylation of $\mathrm{p}-\mathrm{PI} 3 \mathrm{~K}$, and 2.5 and $5 \mu \mathrm{g} / \mathrm{mL}$ of F2 increased $\mathrm{p}-\mathrm{PI} 3 \mathrm{~K}$ to the level more than the control.

Figure 3 showed that palmitate significantly induced the activation of DPP4, while both F1 and F2 were quite effective to down-regulate the activation.

Compared to our previous report, these data of Figs. 2 and 3 revealed that palmitate triggers insulin resistance

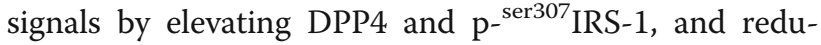
cing p-PI3K. AE subfractions attenuate DPP4 activation and the cascades of insulin resistance.

\section{$A E$ attenuate $A \beta$ generation induced by palmitate}

As palmitate increased the generation of $A \beta 40$ and $\mathrm{A} \beta 42, \mathrm{~F} 1$ and $\mathrm{F} 2$ were effective to reduce the levels of $A \beta$. No significant change was observed for $A \beta 42 / 40$ (Fig. 4). Palmitate enhanced the activity of $\beta$-secretase about 1.2 folds, while $25 \mu \mathrm{g} / \mathrm{mL}$ of $\mathrm{F} 1$ could significantly inhibit $\beta$-secretase. $\mathrm{F} 2$, at $5 \mu \mathrm{g} / \mathrm{mL}$, lowered $\beta$-secretase activity to even below the control (Fig. 5). To investigate whether DPP4 could be involved in the metabolism of $A \beta 40$ and $A \beta 42$, linagliptin (one of the DPP4 inhibitors) was added with palmitate. It was shown that the inhibition of DPP4 was quite valid to attenuate $\beta$-secretase and $A \beta$ generation. These results imply that DPP4 and its signal cascades could be critically involved in the metabolism of $A \beta 40$ and $A \beta 42$ (Fig. 6).

\section{$A E$ attenuate the expression of tau}

The levels of $A \beta 40$ and $A \beta 42$ could be influenced by the process of $A \beta$ degradation. Therefore, in addition to $A \beta$ generation, we observed the expression of IDE. Figure 7 showed that IDE was not altered by $50 \mu \mathrm{M}$ of palmitate. As well, treatment of AE did not affect any expression of IDE.

On the other hand, Tau is another hallmark of AD apart from $A \beta$. It was shown that palmitate induced the phosphorylation of Tau near 1.5 folds. F1, at 5 and $25 \mu \mathrm{g} / \mathrm{mL}$, significantly reduced the expressions of Tau (Fig. 7a). F2, at $2.5 \mu \mathrm{g} / \mathrm{mL}$, was enough to lower p-Tau to the level below the control. At $5 \mu \mathrm{g} / \mathrm{mL}, \mathrm{F} 2$ even reduced $40 \%$ of $\mathrm{p}$-Tau, compared with the control (Fig. 7b).

\section{Discussion}

In the present study, we demonstrated $\mathrm{AE}$ attenuate palmitate-induced DPP-4 activation and insulin resistance cascades. Both F1 and F2 effectively decrease the level of $\mathrm{p}^{-\mathrm{ser} 307}$ IRS-1, and recover the expression of $\mathrm{p}$ PI3K. As palmitate enhances the level of $A \beta, A E$ significantly suppress $A \beta$ generation and $\beta$-secretase activation, while IDE was not altered. The inhibition of DPP4 is quite valid to attenuate $\beta$-secretase activity and the production of $\mathrm{A} \beta$, implying DPP4 and its signal cascades could be critically involved in $\mathrm{A} \beta$ metabolism. Moreover, both F1 and F2 significantly decrease the level of Tau, another hallmark of Alzheimer besides $A \beta$.

$\mathrm{A} \beta$, especially the insoluble 40 - to 42 -amino acid peptide named $A \beta 40$ and $A \beta 42$ respectively, is the principal component of the cerebral plaques found in the brains with Alzeheimer's disease (AD). A $\beta$ is formed by the cleavage of APP. Three proteases $\alpha-, \beta-$, and $\gamma$-secretases cleave APP, and thus be implicated in the etiology of AD. Alpha-secretase exhibits characteristics of certain membrane-tethered metalloproteases. Beta-Secretase is a membrane-anchored protein with clear homology to soluble aspartyl proteases. Gamma-Secretase is an oligomeric complex including presenilins, the pupative catalytic component of this protease [23]. It is well known that two principal metabolic pathways are involved in the processing of APP. The " $\beta$-secretase" pathway mainly generates $A \beta 40 / 42(4-k D)$ by sequential cleavage with $\beta$ and $\gamma$-secretase, and the " $\alpha$-secretase" pathway generates a smaller peptide P3 (3-kD) cleaved with $\alpha$ - and $\gamma$ secretase [24]. The present study focused on $A \beta$ metabolism and " $\beta$-secretase" pathway. Since the activity of $\gamma$ secretase could be involved in another pathway, we evaluated merely $\beta$-secretase but not $\gamma$-secretase. Meanwhile, the level of $A \beta$ could be influenced by its degradation. However, our data showed that the expression of IDE was not altered by palmitate or AE. It can be implied that the dose range applied or the signal cascades are nothing to do with IDE.

Our data showed AE significantly attenuate $A \beta 40$ and $A \beta 42$ induced by palmitate. In fact, $A \beta 42$ aggregates to provide a nidus for the subsequent aggregation of $A \beta 40$, leading to the formation of innumerable neuritic plaques [25]. A spectroscopic analysis revealed that dimeric $A \beta$, derived from mutant APP with a single cysteine in the ectodomain juxtamembrane position, display much more pronounced structural transition than its corresponding monomers. In vivo studies also revealed that 
(A)

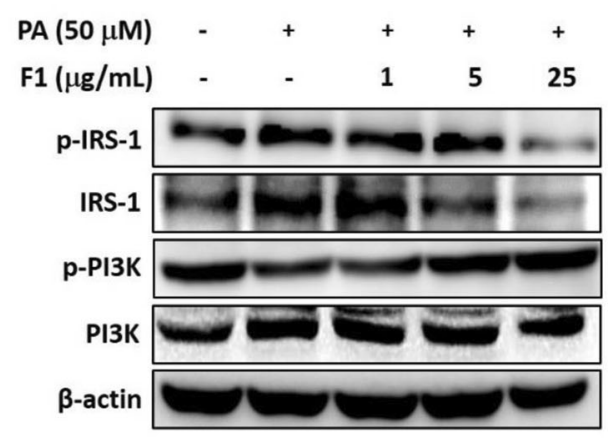

pIRS-1

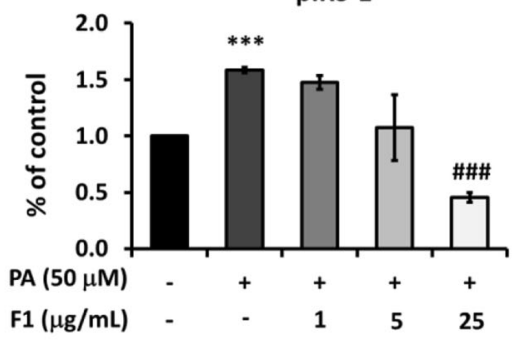

IRS-1
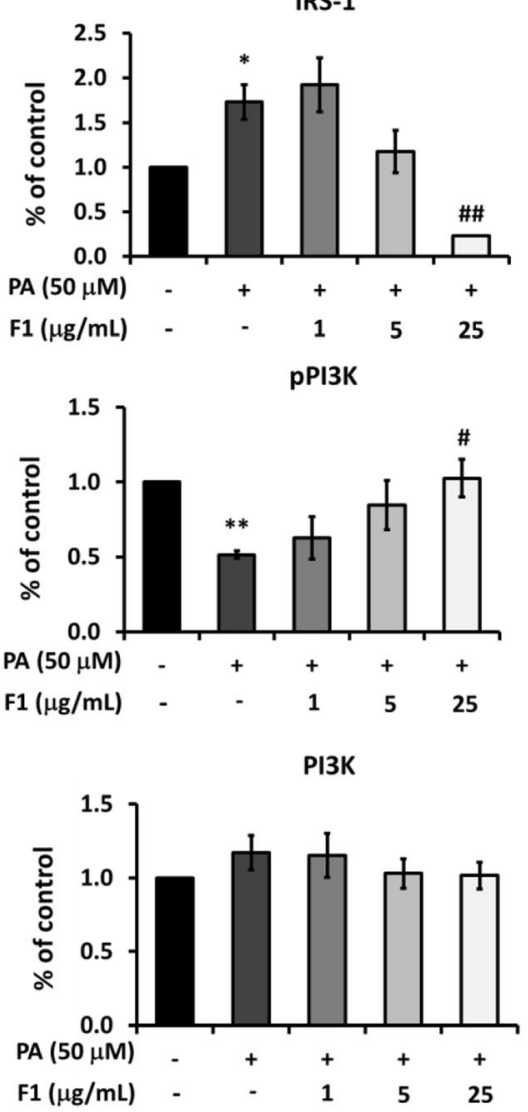

(B)

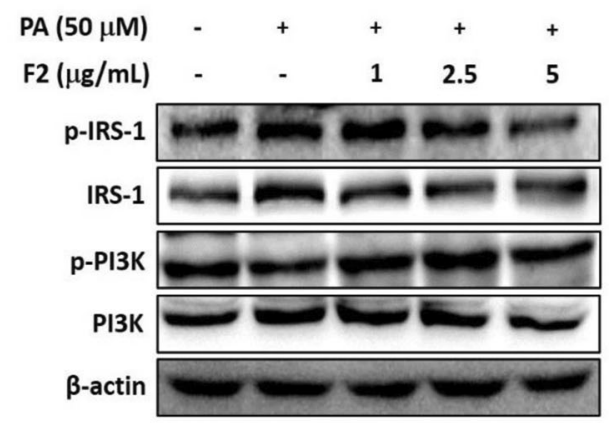

pIRS-1

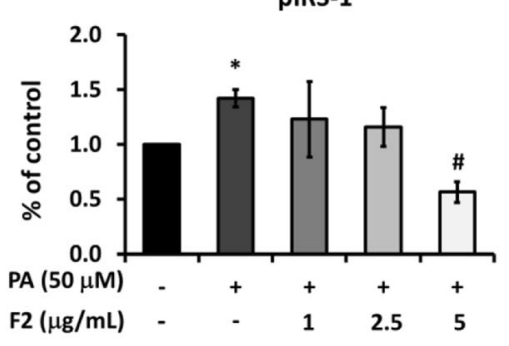

IRS-1
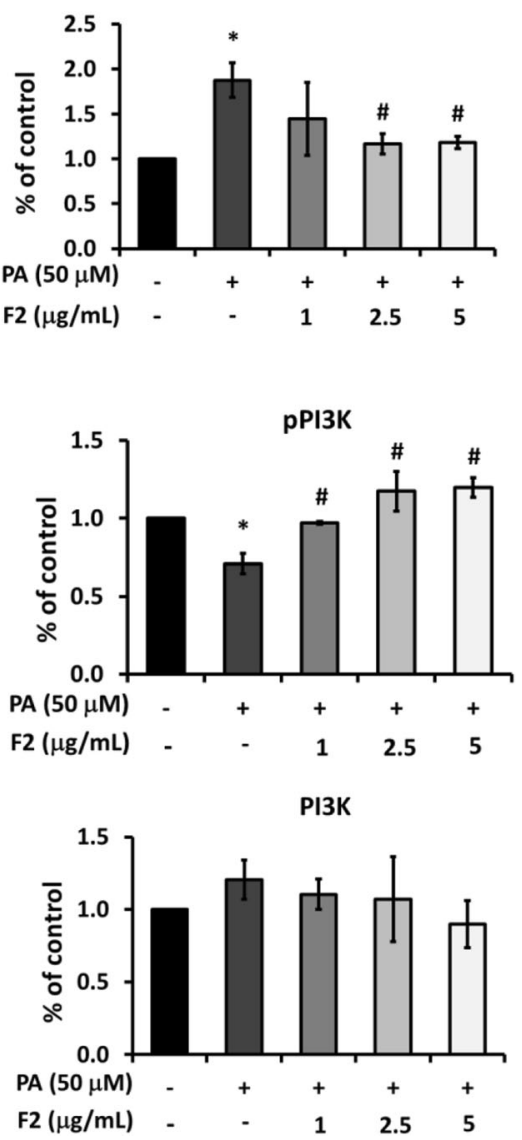

Fig. 2 (See legend on next page.) 
(See figure on previous page.)

Fig. 2 Effect of AE on attenuating insulin resistance signals. SK-N-MC cells were incubated for $24 \mathrm{~h}$ with or without $50 \mu \mathrm{M}$ of palmitate, and with

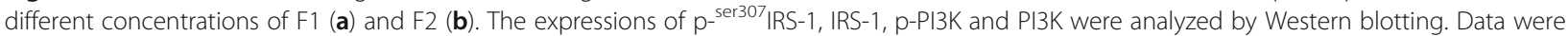
presented as means \pm SD $(n=3)$, and analysed with ANOVA. ${ }^{*} p<0.05,{ }^{* *} p<0.01$, ${ }^{* * *} p<0.001$, compared with the control. \#p $<0.05$, \#p $<0.01$, $\# p<0.001$ compared with the palmitate-treated only

two forms of $A \beta$ homodimers $(A \beta 40$ and $A \beta 42)$ exist, and the dimerization increased beta-sheet content. As reported, the dimeric forms with $\mathrm{C}$-terminal residues Ile- 41 and Ala-42 further increased the beta-sheet content by roughly one-third [26]. It was suggested that the neurotoxic core of $A \beta$ is neurotoxic only when it forms beta-sheet and aggregates [27].

In our previous report, we had demonstrated DPP-4 mediates the insulin resistance signals, leading to the pathological phenomenons associated with diabetes and its complications. Accompanied with increasing p- ${ }^{\mathrm{ser} 307}$ IRS-1 and decreasing p-PI3K, palmitate did hinder glucose uptake in the presence of insulin. Treatment with the polyphenol extracts of Hibiscus sabdariffa (HPE) and DPP-4 inhibitor linagliptin completely recovered insulin sensitivity and palmitateinduced signal cascades, thus decreased AT-1-mediated tubular epithelial to mesenchymal transition [8]. In $\beta$ cells, palmitate induced the signals of DPP-4, p-PI3K and $\mathrm{p}-\mathrm{AMPK}$, and $\mathrm{AE}$ and linagliptin attenuated the signaling cascades. Conversely, palmitate downregulated mTOR, while both F1 and F2 significantly restored the level of mTOR [21]. Actually, in the clinical trial, DPP-4 inhibitor lowered the albuminuria in type 2 diabetic patients, and this was independent of the level of HbA1C [28]. The present investigation showed that linagliptin attenuate palmitate-induced $\beta$-secreatse activity and $A \beta$ generation, implying that DPP-4 could take part in regulating $\mathrm{p}-{ }^{\mathrm{ser} 307} \mathrm{IRS}-1$ and $\mathrm{p}-\mathrm{PI} 3 \mathrm{~K}$, and mediate the development of AD. Noticeably, our recent report indicated that $\mathrm{AE}$ was potential to prevent $\mathrm{A} \beta$ - induced neuron apoptosis by reducing DPP-4 and

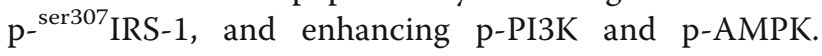
Treatment of linagliptin attenuated the neuron apoptosis induced by $A \beta$ [22]. These results suggest that reciprocal regulations could exist between $A \beta$ metabolism and insulin resistance.

The hyperphosphorylation of Tau is another hallmark of AD. In high fat diet-induced obesity and insulin resistance, the supplementation with Myrciaria jaboticaba berry increased insulin sensitivity, thus prevented tau phosphorylation and improved learning/memory performance [29]. The present data showed that AE attenuate palmitate-induced $\mathrm{p}$-Tau, In comparison with our previous report which revealed $A \beta$ increased $p$ Tau, AE is supposed to attenuate the microtubular change via improving insulin resistance and $A \beta$ generation [22].

F1 and F2 were suggested useful to improve diabetes, insulin resistance, and the associated complications. Quercetin, the component rich in F1, improved cognitive function by inhibiting neurofibrillary tangles mediated by phosphorylated Tau [30]. F2, the most effective AE subfraction in attenuating hyperglycemia and insulin resistance [31], is composed of polysaccharide and sugar derivatives including myoinositol. It was reported intragastric administration of Codonopsis pilosula polysaccharide rescued p-Tau overexpressioninduced cognitive defects [32], and the myoinositol was identified as a molecule inhibiting $\beta$-secretase [33]. Hence the effect of F2 could be at least partly attributed to its polysaccharide and myoinositol.
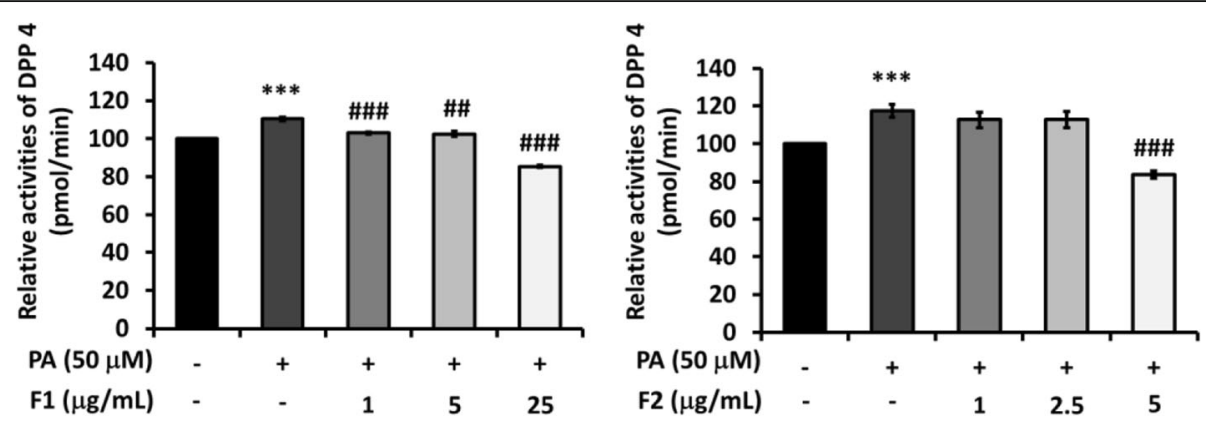

Fig. 3 Effect of AE on attenuating DPP-4 activity. SK-N-MC cells were incubated for $24 \mathrm{~h}$ with or without palmitate, and with different concentrations of F1 and F2, thereby analyzed with DPP-4 activity. The activity of DPP-4 was calculated as a percentage compared with that of the control group. Data were presented as means \pm SD $(n=3)$, and analysed with ANOVA. ${ }^{*} p<0.05,{ }^{* *} p<0.01,{ }^{* * *} p<0.001$, compared with the control. $\# p<0.05, \# p<0.01, \# p<0.001$ compared with the palmitate-treated only 

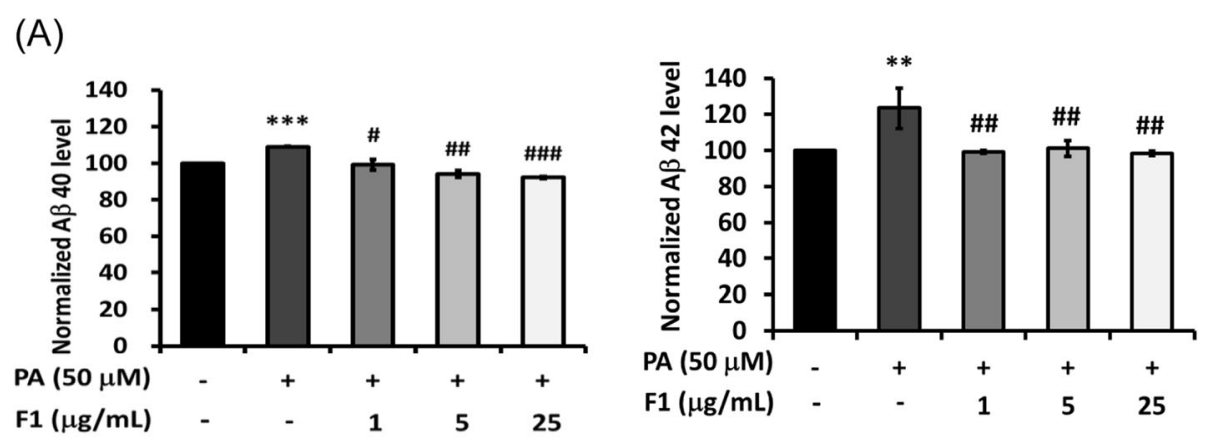

(B)
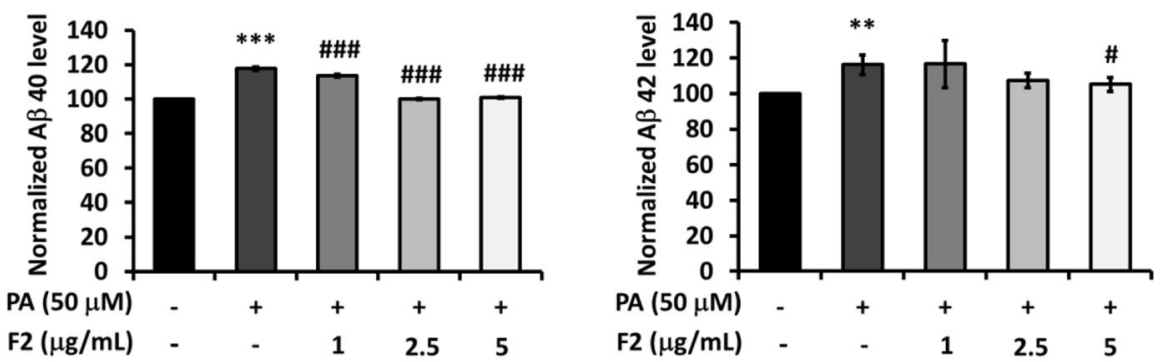

(C)
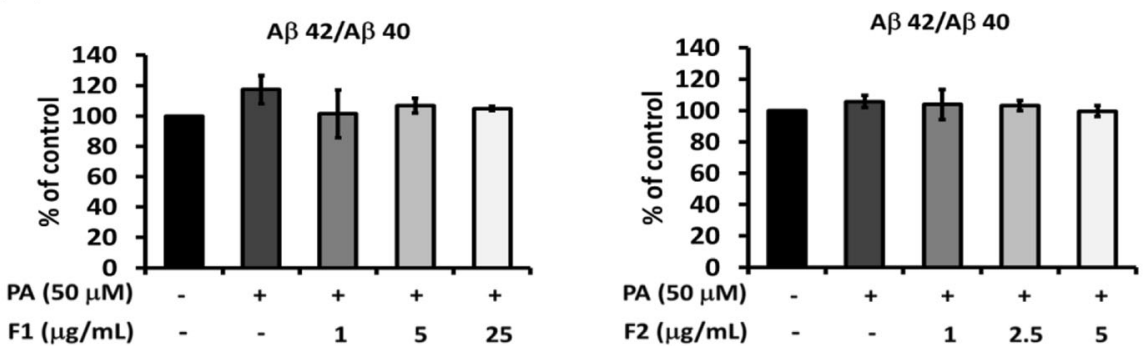

Fig. 4 Effect of $A E$ on attenuating $A \beta$ generation. SK-N-MC cells were incubated for $24 \mathrm{~h}$ with or without palmitate, and with different concentrations of F1 (a) and F2 (b), thereby analyzed with A generation. A $42 / 40$ ratio is shown as (c). Data were presented as means \pm SD $(n=3)$, and analysed with ANOVA. ${ }^{*} p<0.05,{ }^{* *} p<0.01,{ }^{* * *} p<0.001$, compared with the control. $\# p<0.05, \# p<0.01$, \#p $<0.001$ compared with the palmitate-treated only
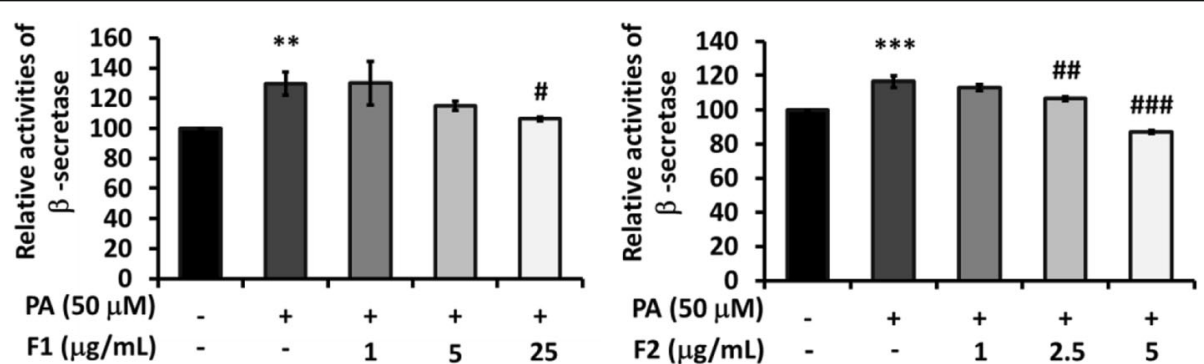

Fig. 5 Effect of AE on attenuating $\beta$-secretase. SK-N-MC cells were incubated for $24 \mathrm{~h}$ with or without palmitate, and with different concentrations of F1 and F2, thereby analyzed with $\beta$-secretase activity. Data were presented as means \pm SD $(n=3)$, and analysed with ANOVA.

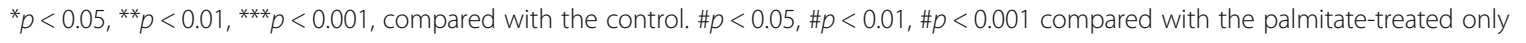



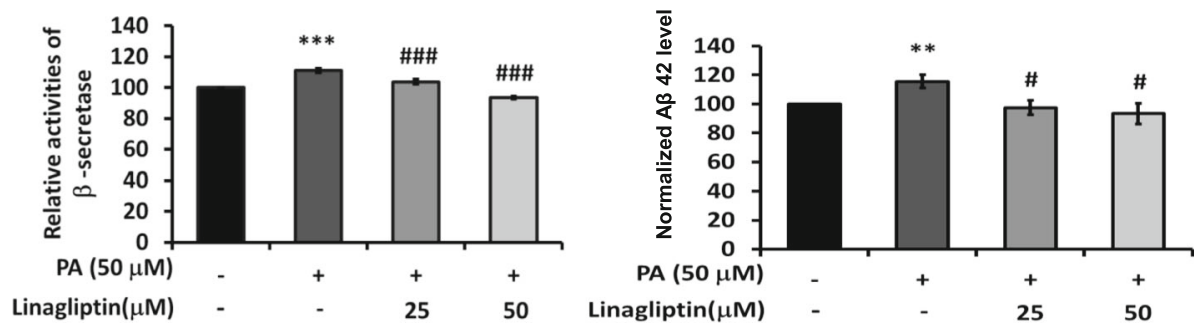

Fig. 6 DPP involved in the expressions of $A \beta$ and $\beta$-secretase. SK-N-MC cells were incubated for $24 \mathrm{~h}$ with or without palmitate, and with different concentrations of linagliptin, thereby analyzed with A $\beta$ generation and $\beta$-secretase activity. Data are presented as means $\pm \operatorname{SD}(n=3)$ and analysed with ANOVA. ${ }^{*} p<0.05,{ }^{* *} p<0.01,{ }^{* * *} p<0.001$, compared with the control. $\# p<0.05, \# p<0.01, \# p<0.001$ compared with the palmitate-treated only

Furthermore, besides the alteration of $\mathrm{p}^{-{ }^{\mathrm{ser}} 307}$ IRS-1, the protein level of IRS-1 displayed a similar change (Fig. 2). This phenomenon may be attributed to the compensation of IRS. In non-diabetic rats, myocardial infarction induced by artery ligation leads to a partial impairment of insulin response. The similar defect might occur in human patients, resulting in compensatory increase of IRS expression [34]. However, the expression of total IRS plunged with $25 \mu \mathrm{g} / \mathrm{mL}$ of F1, but descended steadily with $5 \mu \mathrm{g} / \mathrm{mL}$ of F2. It cannot be ruled out that the phosphorylation change of F1 was caused by destabilizing of protein.

\section{Conclusions}

Therefore, despite both subfracttions of $\mathrm{AE}$ attenuate palmitate-induced insulin resistance and hallmark expression of $\mathrm{AD}, \mathrm{F} 2$ seems more feasible to be developed. In conclusion, we demonstrated that $\mathrm{AE}$ would be a potential adjuvant to prevent insulin resistance and the associated pathogenesis of AD.

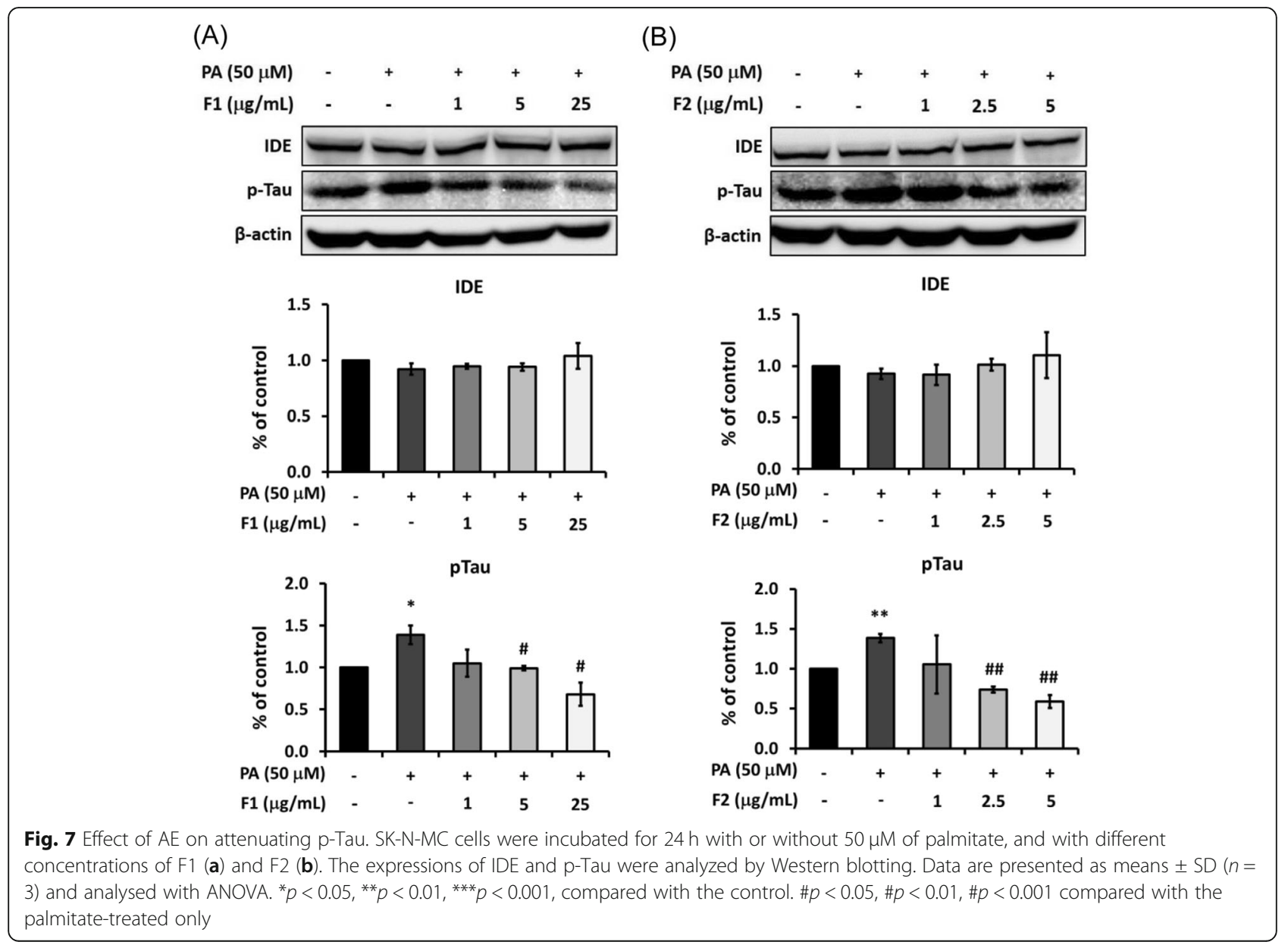




\section{Abbreviations}

AD: Alzheimer disease; A 3 : Beta amyloid; APP: Amyloid precursor protein; IDE: Insulin degradation enzyme; p-tau: Hyperphosphorylation of tau; IRS: Insulin receptor substrates; PI3K: Phosphatidylinositol 3-kinase; p-ser307IRS-1: IRS-1 at ser307; DPP-4: Dipeptidyl peptidase-4; AE: Abelmoschus esculentus, F1 and F2; ATCC: American Type Culture Collection; MEM: Minimum Essential Medium; FBS: Fetal bovine serum; HPE: Hibiscus sabdariffa

\section{Acknowledgements}

The Ministry of Science and Technology of Taiwan is acknowledged for guidance and support. The authors really appreciate everyone who helped us conduct this research.

\section{Authors' contributions}

Conception and design of study: CNH, CHP. Acquisition of data: CJW, CLL, $\mathrm{HHL}$, ATY. Analysis and/or interpretation of data: CJW, CLL. Drafting the manuscript: $\mathrm{CNH}, \mathrm{CHP}$. Revising the manuscript critically for important intellectual content: CNH, CJW, CLL, CHP. The author (s) read and approved the final manuscript

\section{Funding}

This study was supported by the Ministry of Science and Technology, 1082320-B241-003 and 109-2320-B-040-021. Funds were provided to CHP and $\mathrm{CLL}$, and have been utilized for experimentation, analysis and interpretation of data.

\section{Availability of data and materials}

All data/material is available on request from the corresponding author.

\section{Ethics approval and consent to participate}

Not applicable.

\section{Consent for publication}

All authors have read and approved the manuscript.

\section{Competing interests}

I declare that I have no significant competing financial, professional or personal interests that might have influenced the performance or presentation of the work described in this manuscript.

\section{Author details}

'Department of Internal Medicine, Chung-Shan Medical University Hospital, Taichung, Taiwan. ${ }^{2}$ Institute of Medicine, Chung-Shan Medical University, Taichung, Taiwan. ${ }^{3}$ Institute of Biochemistry, Microbiology and Immunology, Chung-Shan Medical University, Taichung, Taiwan. ${ }^{4}$ Division of Basic Medical Science, Hungkuang University, Taichung City, Taiwan.

\section{Received: 3 August 2020 Accepted: 23 November 2020}

Published online: 02 December 2020

\section{References}

1. Maher PA, Schubert DR. Metabolic links between diabetes and Alzheimer's disease. Expert Rev Neurother. 2009:9(5):617-30.

2. Sims-Robinson C, Kim B, Rosko A, Feldman EL. How does diabetes accelerate Alzheimer disease pathology? Nat Rev Neurol. 2010;6(10):551-9.

3. Kopf D, Frölich L. Risk of incident Alzheimer's disease in diabetic patients: a systematic review of prospective trials. J Alzheimers Dis. 2009:16(4):677-85.

4. Ott A, Stolk RP, van Harskamp F, Pols HA, Hofman A, Breteler MM. Diabetes mellitus and the risk of dementia: the Rotterdam study. Neurology. 1999 ; 53(9):1937-42

5. Takeda S, Sato N, Rakugi H, Morishita R. Molecular mechanisms linking diabetes mellitus and Alzheimer disease: beta-amyloid peptide, insulin signaling, and neuronal function. Mol BioSyst. 2011;7(6):1822-7.

6. Cole AR, Astell A, Green C, Sutherland C. Molecular connexions between dementia and diabetes. Neurosci Biobehav Rev. 2007;31(7):1046-63.

7. Choi K, Kim YB. Molecular mechanism of insulin resistance in obesity and type 2 diabetes. Korean J Intern Med. 2010;25(2):119-29.

8. Huang CN, Wang CJ, Yang YS, Lin CL, Peng CH. Hibiscus sabdariffa polyphenols prevent palmitate-induced renal epithelial mesenchymal transition by alleviating dipeptidyl peptidase-4-mediated insulin resistance Food Funct. 2016:7(1):475-82

9. Yamamoto N, Matsubara T, Sobue K, Tanida M, Kasahara R, Naruse K, et al. Brain insulin resistance accelerates $A \beta$ fibrillogenesis by inducing GM1 ganglioside clustering in the presynaptic membranes. J Neurochem. 2012; 121(4):619-28

10. Gasparini L, Netzer WJ, Greengard P, Xu H. Does insulin dysfunction play a role in Alzheimer's disease? Trends Pharmacol Sci. 2002;23(6):288-93.

11. Phiel CJ, Wilson CA, Lee VM, Klein PS. GSK-3alpha regulates production of Alzheimer's disease amyloid-beta peptides. Nature. 2003;423(6938):435-9.

12. Qiu WQ, Folstein MF. Insulin, insulin-degrading enzyme and amyloid-beta peptide in Alzheimer's disease: review and hypothesis. Neurobiol Aging. 2006:27(2):190-8.

13. Qiu WQ, Walsh DM, Ye Z, Vekrellis K, Zhang J, Podlisny MB, et al. Insulindegrading enzyme regulates extracellular levels of amyloid beta-protein by degradation. J Biol Chem. 1998;273(49):32730-8.

14. Li H, Wu J, Zhu L, Sha L, Yang S, Wei J, et al. Insulin degrading enzyme contributes to the pathology in a mixed model of type 2 diabetes and Alzheimer's disease: possible mechanisms of IDE in T2D and AD. Biosci Rep. 2018;38(1):BSR20170862

15. Cao D, Lu H, Lewis TL, Li L. Intake of sucrose-sweetened water induces insulin resistance and exacerbates memory deficits and amyloidosis in a transgenic mouse model of Alzheimer disease. J Biol Chem. 2007:282(50):36275-82.

16. Robinson A, Lubitz I, Atrakchi-Baranes D, Licht-Murava A, Katsel P, Leroith D, et al. Combination of insulin with a GLP1 agonist is associated with better memory and Normal expression of insulin receptor pathway genes in a mouse model of Alzheimer's disease. J Mol Neurosci. 2019;67(4):504-10.

17. Council NR. Lost crops of Africa: volume II: vegetables. Washington, DC: The National Academies Press; 2006.

18. Chiu N, Chang K. The illustrated medicinal plants in Taiwan. Taipeiln Chinese: SMC Publ. Inc; 1995

19. Peng $\mathrm{CH}$, Chyau CC, Wang CJ, Lin HT, Huang CN, Ker YB. Abelmoschus esculentus fractions potently inhibited the pathogenic targets associated with diabetic renal epithelial to mesenchymal transition. Food Funct. 2016 7(2):728-40

20. Peng $\mathrm{CH}$, Lin $\mathrm{HC}$, Lin CL, Wang CJ, Huang CN. Abelmoschus esculentus subfractions improved nephropathy with regulating dipeptidyl peptidase-4 and type 1 glucagon-like peptide receptor in type 2 diabetic rats. J Food Drug Anal. 2019;27(1):135-44

21. Huang CN, Wang CJ, Lee YJ, Peng CH. Active subfractions of Abelmoschus esculentus substantially prevent free fatty acid-induced $\beta$ cell apoptosis via inhibiting dipeptidyl peptidase-4. PLoS One. 2017;12(7):e0180285.

22. Huang CN, Wang CJ, Lin CL, Yen AT, Li HH, Peng CH. Abelmoschus esculentus subfractions attenuate beta amyloid-induced neuron apoptosis by regulating DPP-4 with improving insulin resistance signals. PLoS One 2019;14(6):e0217400

23. Esler WP. Wolfe MS. A portrait of Alzheimer secretases--new features and familiar faces. Science (New York, NY). 2001;293(5534):1449-54.

24. Gouras GK, Xu H, Jovanovic JN, Buxbaum JD, Wang R, Greengard P, et al. Generation and regulation of beta-amyloid peptide variants by neurons. J Neurochem. 1998:71(5):1920-5

25. Lemere CA, Lopera F, Kosik KS, Lendon CL, Ossa J, Saido TC, et al. The E280A presenilin 1 Alzheimer mutation produces increased a beta 42 deposition and severe cerebellar pathology. Nat Med. 1996;2(10):1146-50.

26. Schmechel A, Zentgraf H, Scheuermann S, Fritz G, Pipkorn R, Reed J, et al. Alzheimer beta-amyloid homodimers facilitate a beta fibrillization and the generation of conformational antibodies. J Biol Chem. 2003;278(37):35317-24.

27. Hirakura Y, Satoh Y, Hirashima N, Suzuki T, Kagan BL, Kirino Y. Membrane perturbation by the neurotoxic Alzheimer amyloid fragment beta 25-35 requires aggregation and beta-sheet formation. Biochem Mol Biol Int. 1998;46(4):787-94.

28. Groop PH, Cooper ME, Perkovic V, Emser A, Woerle HJ, von Eynatten M. Linagliptin lowers albuminuria on top of recommended standard treatment in patients with type 2 diabetes and renal dysfunction. Diabetes Care. 2013; 36(11):3460-8.

29. Batista ÂG, Soares ES, Mendonça MCP, da Silva JK, Dionísio AP, Sartori CR, et al. Jaboticaba berry peel intake prevents insulin-resistance-induced tau phosphorylation in mice. Mol Nutr Food Res. 2017;60:10.

30. Qi Y, Guo L, Jiang Y, Shi Y, Sui H, Zhao L. Brain delivery of quercetin-loaded exosomes improved cognitive function in AD mice by inhibiting phosphorylated tau-mediated neurofibrillary tangles. Drug Delivery. 2020; 27(1):745-55. 
31. Huang $C N$, Wang $C$, Lin $C L$, Lin $H T$, Peng $C H$. The nutraceutical benefits of subfractions of Abelmoschus esculentus in treating type 2 diabetes mellitus. PLoS One. 2017;12(12):e0189065.

32. Zhang Q, Xia Y, Luo H, Huang S, Wang Y, Shentu Y, et al. Codonopsis pilosula polysaccharide attenuates tau hyperphosphorylation and cognitive impairments in hTau infected mice. Front Mol Neurosci. 2018;11:437.

33. Abe TK, Taniguchi M. Identification of myo-inositol hexakisphosphate (IP6) as a $\beta$-secretase 1 (BACE1) inhibitory molecule in rice grain extract and digest. FEBS Open Bio. 2014;4:162-7.

34. Jiménez-Navarro MF, Bueno H, Alvarez-Sala L, Rodríguez-Losada N, Andrés V, González-Navarro H. Insulin receptor substrate-1 expression is increased in circulating leukocytes of patients with acute coronary syndrome. ISRN Cardiol. 2011;2011:740585.

\section{Publisher's Note}

Springer Nature remains neutral with regard to jurisdictional claims in published maps and institutional affiliations.

Ready to submit your research? Choose BMC and benefit from:

- fast, convenient online submission

- thorough peer review by experienced researchers in your field

- rapid publication on acceptance

- support for research data, including large and complex data types

- gold Open Access which fosters wider collaboration and increased citations

- maximum visibility for your research: over $100 \mathrm{M}$ website views per year

At BMC, research is always in progress.

Learn more biomedcentral.com/submissions 